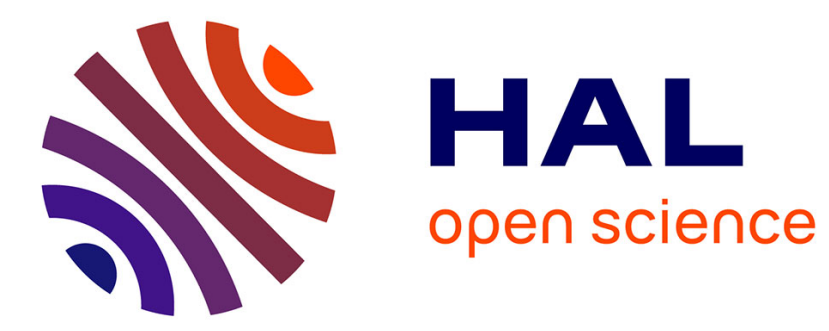

\title{
Ovulation as danger signaling event of innate immunity
}

Katharina Spanel-Borowski

\section{To cite this version:}

Katharina Spanel-Borowski. Ovulation as danger signaling event of innate immunity. Molecular and Cellular Endocrinology, 2011, 333 (1), pp.1. 10.1016/j.mce.2010.12.008 . hal-00660887

\section{HAL Id: hal-00660887 https://hal.science/hal-00660887}

Submitted on 18 Jan 2012

HAL is a multi-disciplinary open access archive for the deposit and dissemination of scientific research documents, whether they are published or not. The documents may come from teaching and research institutions in France or abroad, or from public or private research centers.
L'archive ouverte pluridisciplinaire HAL, est destinée au dépôt et à la diffusion de documents scientifiques de niveau recherche, publiés ou non, émanant des établissements d'enseignement et de recherche français ou étrangers, des laboratoires publics ou privés. 


\section{Accepted Manuscript}

Title: Ovulation as danger signaling event of innate immunity

Author: Katharina Spanel-Borowski

PII:

DOI:

S0303-7207(10)00571-X

Reference: doi:10.1016/j.mce.2010.12.008

MCE 7713

To appear in: $\quad$ Molecular and Cellular Endocrinology

Received date: $\quad 2-12-2010$

Accepted date: $\quad 3-12-2010$

Please cite this article as: Spanel-Borowski, K., Ovulation as danger signaling event of innate immunity, Molecular and Cellular Endocrinology (2010), doi:10.1016/j.mce.2010.12.008

This is a PDF file of an unedited manuscript that has been accepted for publication. As a service to our customers we are providing this early version of the manuscript. The manuscript will undergo copyediting, typesetting, and review of the resulting proof before it is published in its final form. Please note that during the production process errors may be discovered which could affect the content, and all legal disclaimers that apply to the journal pertain. 


\section{Ovulation as danger signaling event of innate immunity}

Running title: Ovulation as danger signaling

\section{Katharina Spanel-Borowski}

Institute of Anatomy, University of Leipzig, Liebigstrasse 13, D-04103 Leipzig, Germany

Word count of main text (abbreviations, abstract, legends and references excluded): 3821

Corresponding author:

Katharina Spanel-Borowski, MD, Ph.D.

Institute of Anatomy, University of Leipzig, Liebigstraße 13, 04103 Leipzig, Germany;

telephone +49 341-9722053, fax +49 341-9722009

e-mail: spanelb@medizin.uni-leipzig.de 


\section{Abbreviations}

ADAMTS, a disintegrin and metalloproteinase with thrombospondin motifs; AGE,advanced glycation end-products; b-FGF, basic fibroblast factor; C1q, complement subunit 1q; C3a/5a, complement subunit $3 \mathrm{a}$ and $5 \mathrm{a}$; $\mathrm{CK}$, cytokeratin; $\mathrm{CK}$, cytokeratin-negative; $\mathrm{CK}^{+}$, cytokeratinpositive; CL, corpus luteum; EGF, epidermal growth factor; FSH, follicle stimulating hormone; HMGB1, high mobility group box-1 protein; IFN, interferon; IL, interleukin; INIM, innate immunity; KIT, CD117 tyrosin kinase receptor; $\mathrm{KIT}^{+,}$KIT-positive; LH, luteinizing hormone; LOX-1, lectin-like oxidized low density lipoprotein receptor 1; Myd88, myeloid differentiation factor 88; NK-1R, neurokinin-1 receptor; NF-kB , nuclear factor kB; oxLDL, oxidized low density lipoprotein; PCOS, polycystic ovary syndrome; PPRs, patternrecognition receptors; RANTES, regulated on activation, normal $\mathrm{T}$ cell expressed and secreted; ROS, reactive oxygen species; SP, substance P; TLR, toll-like receptor family; TIR, toll-IL-1 receptor domain; TNF, tumor necrosis-factor; TRIF , TIR-domain-containing adaptor protein producing IFN type I; TGF- $\beta$, tumor necrosis factor $\beta$; VEGF, vascular endothelial cell growth factor; Wnt, wingless 


\begin{abstract}
The ovulatory process is characterized by tissue wounding and, after oocyte expulsion, by healing being connected to the formation of a corpus luteum (CL). The ovulatory event thus compares with a sterile inflammation. The concept is forwarded that the ovulatory process depends on innate immunity (INIM) function. The ultimate trigger for INIM signaling are danger signals/alarmins from granulosa cells damaged by oxidative stress and reactive oxygen species (ROS), respectively. Alarmins like oxidized low density lipoprotein (oxLDL) are recognized by cytokeratin-positive $\left(\mathrm{CK}^{+}\right)$granulosa cells with the expression of toll-like receptor 4 (TLR4). The subsequent inside-out signaling from the antrum towards the thecal cell layer comprises inflammation and tissue disintegration, which might be dominated by the myeloid differentiation factor 88 (Myd88) gateway. Additive or co-regulatory function are expected from the complement cascade for vessel permeability and leukocyte immigration and the wingless (WnT)-signaling for cell adhesion of $\mathrm{CK}^{+}$granulosa cells. The outside-insignaling relates to the repair phase, which is primarily controlled by the TIR-domaincontaining adaptor protein producing IFN type I (TRIF) gateway of TLR signaling. The KIT/CD117 tyrosine kinase receptor and the tachykinin-tachykinin receptor system could be involved. The appealing concept of INIM function in the ovary is novel and inaugurates a novel research field.
\end{abstract}

Key words: Ovulation, preovulatory follicle, oxidative stress, innate immunity , cytokeratinpositive granulosa cells, toll-like receptor 4 , signaling pathways

\title{
1. Introduction
}

The ovulatory process subdivides into three phases: the inflammatory phase, the rupture event, and the repair phase (Espey, 1994; Oktem and Oktay, 2008). Inflammation with leukocyte recruitment, vessel permeability and formation of capillary sprouts develops in the wall of a preovulatory follicle within 12 hours in humans and a few hours in small rodents like mice, rats, and hamsters. The rupture phase starts at the follicle apex with degradation of the basement membrane and contraction of smooth-muscle type thecal cells for expulsion of the oocyte into the Fallopian tube. The rupture event of one hour in humans primarily depends on the activation of matrix metalloproteinases and of prostaglandin E. The repair phase extends over three days in humans, comprises ingrowth of connective tissue and of capillaries 
from the vascular thecal cell layer into the former avascular granulosa cell layer (Stocco et al., 2007; Devoto et al., 2009). Both cell layers undergo luteinization showing the small lutein cells in the periphery of a young CL and the large lutein cells in the former granulosa cell layer and antrum space.

The three phases are generally considered as entity. The general interest focuses on molecular patterns for capillary sprouting and on the recruitment of leukocyte subtypes in the preovulatory follicle wall (Brännström and Enskog, 2002; Fraser and Duncan, 2005; Berisha and Schams, 2005;). The third phase is neglected as repair phase of the damaged follicle and rather attributed to the formation of the CL. It is also overseen that the three phases represent the classical sequence of an acute sterile inflammation comprising tissue wounding and repair under the command of INIM (Medzhitov, 2008, 2010a; Rock et al., 2010). Innate immunity comes first to recognize danger signals whether they might come from infectious invaders or from dying and dead cells (Turvey and Broide, 2010). Among specialized INIM cells are the dendritic cells (DCs) being densely equipped with pattern-recognition receptors (PRRs; (O'Neill and Bowie, 2007; Takeuchi and Akira, 2010). The receptor name is derived from the capacity to recognize patterns/complexes of e.g. lipids, of proteins, of nucleic acids being in contrast to the selective antigen recognition by lymphocyte receptors of the adaptive immunity. The discovery of PRRs has generated the danger model as novel immune concept stating that nonself molecules belong to danger signals as superior force of immunoresponse activation (Matzinger, 2002, 2007). Any tissue/cell damage is associated with the release of danger signals, termed alarmins (Bianchi, 2007). They bind to PPRs and the subsequent signaling cascade has the capacity to activate a plethora of genes. They control cell death/growth, inflammation (leukocyte recruitment, angiogenesis, tissue disintegration) as well as anti-inflammation with tissue repair (O'Neill and Bowie, 2007; Takeuchi and Akira, 2010). Presently, the PRRs consist of four families among them the toll-like receptor (TLR) family with 12 members in the mouse. The PPRs signaling cascade has a good and a bad side of a coin. In case of wounding, the INIM pathway is well balanced for healing to achieve the quick recovery of tissue integrity. On the other hand, an unbalanced action can cause chronic tissue injury and autoimmune diseases.

The cyclic ovary is a site of tissue damage and healing related to follicular atresia, follicle rupture, CL formation and regression (Spanel-Borowski, 2010). It is a place where the physiological ability of INIM function is being revealed. Convincing hints that the ovulatory process is under immunosurveillance comes from gene expression analysis of granulosa/cumulus cells. They show genes like members of the TLR family ( $T l r 2,4,8$ and 9), 
the TLR adaptor molecules $C d 14, C 1 q$ and $M y d 88$ that all have been exclusively found in immune cells (Shimada et al., 2006; Shimada et al., 2008; Richards et al., 2008). In our opinion, immunosurveillance of the ovulatory process compares with the INIM answer in the backs of the endocrine system. The circumscribed damage of the follicle wall and the subsequent healing is managed like an acute sterile inflammation (Medzhitov, 2008, 2010a; Rock et al., 2010). It appears that INIM trains its specific immune cells according to the need of the ovary (Matzinger, 2007). The inflammatory reaction remains limited to the follicle because signaling transfer to the adaptive immunity is likely minor (Iwasaki and Medzhitov, 2010; Medzhitov, 2010a). The provocative hypothesis is that, in the very final run of the ovulatory process, danger signals dramatically increase in the follicle compartment. Derived from damaged granulosa/cumulus cells, danger signals are sensed to activate the ovarian INIM system. The promising candidate for danger sensing are the $\mathrm{CK}^{+}$granulosa cells, which regulate TLR4 expression under oxLDL treatment in culture (Serke et al., 2009; Serke et al., 2010). The molecular steps and the cytokine profile generated by the activation cascade in $\mathrm{CK}^{+}$cells are unknown. Yet evidence is given by gene analysis that the expression of inflammatory immunrelated genes starts in the granulosa cell layer (Shimada et al., 2006; Shimada et al., 2008; Richards et al., 2008).

\section{Danger in preovulatory follicles for onset of INIM function}

Oxidative stress is recognized as an important factor in aging structures. The preovulatory follicle represents an aging structure, because it is the terminal stage of a record extending from fetal period to ovulation time (Tatone et al., 2008). Therefore, the prevulatory follicle is likely more susceptible to oxidative stress than preceding follicle stages. Oxidative stress relates to the production of ROS as byproducts of full speed steroidogenesis in preovulatory granulosa cells (Hanukoglu, 2006). ROS is released from the mitochondrial respiratory chain through leaky membranes. Degenerating mitochondria in human granulosa cells from fresh follicle aspirates are judged as sign of ROS damage (Vilser et al., 2010). Another ROS source translates to a granulosa cell subtype without $\mathrm{CK}$ filaments, termed $\mathrm{CK}$-negative $\left(\mathrm{CK}^{-}\right)$ granulosa cell. It expresses the lectin-like oxidized low density lipoprotein receptor 1 (LOX1), a specific scavenger receptor for oxLDL (Duerrschmidt et al., 2006; Serke et al., 2009). The oxLDL-dependent LOX-1 regulation in $\mathrm{CK}^{-}$granulosa cells is probably associated with ROS production as deduced from endothelial cell studies. They show ROS as byproduct of oxLDL- dependent LOX-1 signaling, and, in a vicious internal feedback, the ROS-dependent 
LOX-1 increase, which amplifies oxLDL binding and the subsequent signaling cascade. Cell death ensues (Mehta et al., 2006; Chen et al., 2007). The amount of ROS determines beneficial or detrimental effects, either for endothelial cell survival or apoptosis (Dandapat et al., 2007). The same could hold true for the preovulatory follicle. Moderate ROS levels might do no harm, because cultured $\mathrm{CK}^{-}$granulosa cells treated with $150 \mu \mathrm{g} / \mathrm{ml}$ oxLDL respond by survival autophagy (Serke et al., 2009). High ROS levels can cause cell death. Of note, oxLDL, which is oxidized from normal lipoprotein under ROS influence, is higher in concentration in the follicular fluid of obese women either with or without a polycystic ovary syndrome (PCOS) compared to normal-weight patients (Bausenwein et al., 2010). It is assumed that the damaged granulosa cells actively secrete alarmins or passively release them after death (Bianchi, 2007). Alarmins are often leaderless proteins, thus having a non-classical secretory pathway through exosomes. The growing list of alarmins comprise acute phase proteins, S100 proteins, advanced glycation end-products (AGE), high mobility group box-1 protein (HMGB1), defensins and interleukin-1 $\alpha$ (IL-1 $\alpha$ ), which all are present in follicle cells and the follicular fluid of preovulatory follicles (Angelucci et al., 2006; Richards et al., 2008; Tatone et al., 2008; Grøndahl et al., 2009). Alarmins can engage IL-1 receptor, AGE receptor and TLRs. Because TLR4 is also a receptor for oxLDL (Takeda and Akira, 2005), this lipoprotein could act like an alarmin.

The fresh follicle harvest from women under in vitro therapy contains between $20-50 \%$ dead granulosa cells depending on reproductive age, body weight and total follicle stimulating hormone (FSH) dose of the stimulation protocol (Vilser et al., 2010). The high range of dead cells is explained by different degrees of oxidative stress, thus not only attributed to the gonadotropin releasing hormone treatment, which induces classical apoptosis at the level of the ovary (Tsai et al., 2005; Giampietro et al., 2006). Different degrees of oxidative stress could modify different forms of cell death, which appear to occur simulteously in mature follicles (van Wezel et al., 1999; Stocco et al., 2007; Serke et al., 2009; Vilser et al., 2010). The interesting point is to unravel the danger signaling loops for either apoptosis, necrosis or cell-death autophagy in granulosa cell subtypes.

The preovulatory follicle is a structure under oxidative stress, as has been forwarded by other groups. They have been interested to find correlations between oxidant/antioxidant levels in the follicular fluid and the oocyte quality, rate of fertilization and of implantation as well as embryo development (Oyawoye et al., 2003; Pasqualotto et al., 2004; Das et al., 2006; Appasamy et al., 2008). Our concept judges oxidative stress as final release mechanism of the ovulatory event. It is triggered by danger signals from dead granulosa cells and danger 
sensing by intact $\mathrm{CK}^{+}$cells with danger receptors like TLR4. In other words, oxidative stress activates INIM force to orchestrate the ovulatory process (Fig. 1A).

\section{The $\mathrm{CK}^{+}$granulosa cells as danger sensor and potential DCs}

Not the fibroblast-like $\mathrm{CK}^{-}$cell type, only the epithelioid $\mathrm{CK}^{+}$granulosa cell type respond to the treatment of oxLDL, nLDL and serum-free medium by upregulating TLR4 and CD14 (Serke et al., 2009; Serke et al., 2010). In addition, ROS generation is increased, whereas steroiodgenesis is decreased (Serke et al., 2009). For this reason, the $\mathrm{CK}^{+}$cells have come into sight as danger sensor through the TLR4 cascade being induced by oxLDL. The $\mathrm{CK}^{+}$cells confer two complex signaling pathways leading to immunoresponses and inflammatory cytokines (Kumar et al., 2009; Takeuchi and Akira, 2010). The Myd88-dependent nuclear factor $\mathrm{kB}(\mathrm{NF}-\mathrm{kB})$ pathway could explain peak values of tumor necrosis factor $\alpha$, interleukin$1 \beta$ and interleukin-6 (TNF- $\alpha$, Il-1 $\beta$, IL-6) in preovulatory follicles (Adashi, 1990; Brännström et al., 1994a), and the mitogen-associated-protein-kinases (MAPks) signaling for inflammation and tissue disintegration (Fig. 1A). The TLR-Il-1 receptor domain (TIR)dependent pathway of TLR signaling causes the activation of interferon (IFN) type I $(\alpha, \beta)$ genes mediating anti-inflammatory responses (Fig. 1B). The two multipurpose TLRdependent pathways are ancient signaling systems as are the complement cascade, wingless (Wnt) signaling, and the tachykinin-tachykinin-receptor system (Severini et al., 2002; Köhl, 2006; Pereira et al., 2009). These cascades compare in evolution with the development of INIM roughly 600 millions of years ago (Endo et al., 2006; Turvey and Broide, 2010). The possible co-regulation is indicated for the complement and Wnt system (Gordon et al., 2005; Hajishengallis and Lambris, 2010). The signal cascades might act independently or become co-regulatory partners of the TLR pathways at receptor level or downstream of the signaling pathway. For example, TLR4 activation requires the heterodimerization with CD 14 or CD36 as co-regulatory receptors (Miller et al., 2003; Stewart et al., 2010). The dominance of one of the postulated co-regulatory partners could mediate specific signaling changes in the TLR regulatory loop. In the rupture phase (Fig. 1A), the complement-dependent co-regulation might contribute to changes in fibrinolytic activity, vessel permeability, leukocyte immigration connective tissue degradation (Köhl, 2006; Hajishengallis and Lambris, 2010). The canonical Wnt signaling for $\beta$-catenin production could mediate adherens junction formation to create a microenvironment between $\mathrm{CK}^{+}$cells as given evidence for uterine development, pre-implantation and decidualisation (Sonderegger et al., 2010). In this line is 
the report on Wnt4 knock out mice showing disturbed follicle development and infertility (Boyer et al., 2010). In the late phase of the ovulatory event (Fig. 1B), the modification of TLR signaling is suggested to rely on the co-regulation of the tachykin-tachkinin receptor system. The cooperation might guide the anti-inflammatory response for tissue repair (see 4).

The special nature of $\mathrm{CK}^{+}$cells dates back to early fetal life when primordial follicles with $\mathrm{CK}^{+}$cells arise from the medullary part of sex cords in the aorta-gonado-mesonephros region. The $\mathrm{CK}^{+}$cells are transiently unapparent in growing follicles, and reappear in preovulatory follicles as well as in freshly ruptured follicles and in the forming CL (Löffler et al., 2000). The $\mathrm{CK}^{+}$cells are assumed to switch off the CK genes in the CL stage of secretion and regression to become granulosa-like cells as extensively documented (Spanel-Borowski, 2010). The reasons for the risky statement relates to the in situ observation on steroidogenic luteal cells with decreasing CK intensities and to the successful cultivation of granulosa-like luteal cells. They depict long and thin DC-like processes at the ultrastructural level. The granulosa-like cells are well maintained under the treatment with $200 \mathrm{IU} / 0.5 \mathrm{ml} \mathrm{IFN}-\gamma$ with the tendency to increase cell number and adhesion molecules like $\mathrm{N}$-cadherin and neuronal cell adhesion molecule-140. Additionally, the major histocompatibility complex class II is upregulated by 80 fold in granulosa-like cells compared to basal levels. Collectively, the granulosa-like cells reminds of DCs, which typically respond in a constructive manner to IFN- $\gamma$, a key regulator of DC function in INIM (Billiau and Matthys, 2009). The big task is to prove that the metamorphosis from $\mathrm{CK}^{+}$cell to the granulosa-like cell is associated with the ability of antigen-presentation and with naïve T cell training.

\section{Eosinophils and tachykinin expression for tissue repair in INIM function}

In the preovulatory follicle wall, mast cells appear to be absent and the number of $\mathrm{T}$ cells as main representatives of the adaptive immune system are low in number (Best et al., 1996; Spanel-Borowski et al., 1997; Bauer et al., 2001). It points to a minor cross-talk between

INIM and adaptive immunity. Segmented leukocytes densely populate the follicle wall being neutrophils or eosinophils obviously in dependence of the species and of the early or late ovulatory phase. In small rodents with a 4-day-estrous cycle, neutrophils are found in the follicle wall (Brännström et al. 1994b; Brännström et al., 1994b; Brännström and Enskog, 2002), whereas, in human and bovine follicles in the transition to a CL, the CD18-positive leukocyte pool relate to 90\% of eosinophils (Aust et al., 2000; Reibiger and Spanel-Borowski, 2000). Their classical role in parasite infections is here extended to sterile inflammation as 
INIM function. Eosinophils are involved in immunoregulation, angiogenesis and tissue repair (Munitz and Levi-Schaffer, 2004; Blanchard and Rothenberg, 2009). Eosinophils are likely not innocent bystanders, but active participants in the developing CL. The favourite influence could relate to vessel stabilization as wells as to the fibrogenic capacity with fibroblast proliferation and collagen synthesis under the influence of eosinophilic vascular endothelial cell growth factor (VEGF), b-fibroblast growth factor (b-FGF), and transforming growth factor $\beta$ (TGF- $\beta$ ). Eosinophil recruitment into the ruptured follicle could be guided by the regulated on activation, normal $\mathrm{T}$ cell expressed and secreted (RANTES) molecule, because it is increased in tumor necrosis-factor $\alpha(\mathrm{TNF}-\alpha)$ treated granulosa cell cultures (Aust et al., 2000). Additionally, L-selectin (CD62L) on eosinophils and the counterreceptor (CD62P) on microvascular endothelial cells being highly expressed in the developing CL seem to be involved (Rohm et al., 2002). The influence of tachykinins, in particular of substance P (SP)like molecules, and its neurokinin-1 receptor (NK-1R) are also considered for specifying eosinophil function. The tachykinin family comprises members like SP, neurokinin A and B, and endokinins all derived from separate preprotachykinin genes and precursor proteins (Severini et al., 2002). The neurogenic inflammation in allergic and chronic inflammatory disorders correlates with eosinophil accumulation, elevated levels of SP and NK-1R in diseases of the lung, gut and joints (O'Connor et al., 2004). In respect to the bovine ovary, the periphery of the freshly ruptured follicle displays a network of SP-like structure in immunofluoresence staining and, in gene analysis, the preprotachykinin I as well as the NK1R (Reibiger et al., 2001). Mice gene-deficient for the NK-1R gene display signs of the luteinized and unruptured follicle syndrome, which lacks oocyte expulsion, yet develops functional CL (Qublan et al., 2006; Löffler et al., 2004b). Evidence is collected that the tachykinin-tachykinin receptor system is influential as intraovarian modulator in granulosa and luteal cells (Löffler et al., 2004a; Brylla et al., 2005; Debeljuk, 2006). Collectively, the neuropeptide system might be part of the acute INIM answer to optimize the repair phase through eosinophil specification (Lambrecht, 2001). The exact cell source of tachykinin production awaits clarification for the young CL. That eosinophils might indicate a specific immunoresponse in the CL, has been forwarded many years ago (Murdoch and Steadman, 1991).

\section{Inside-out and outside-in-signaling as INIM order}


The general opinion is that degradation of the follicle wall starts somewhere outside. The surface epithelial cells close to the preovulatory follicle are said to release factors in support of connective tissue degradation. This opinion should be discarded, because follicle rupture occurs in spite of denudation of the surface epithelium (Wright et al., 2010). Additionally, superovulated ovaries form rats, golden hamsters and rabbits develop atypical follicle ruptures with intra-ovarian oocyte release (Spanel-Borowski, 2010). Under the luteinizing hormone (LH) surge, genes for the two essential pathways [progesterone-receptor pathway for protease production like ADAMTS-1 (a disintegrin and metalloproteinase with thrombospondin motifs), cathepsin L and the epidermal growth factor (EGF)-superfamily signaling for cumulus expansion] are predominantly detected in the granulosa cell layer (Espey, 2006; Richards et al., 2002; Hernandez-Gonzalez et al., 2006). All of these observations point to a degradation process from the interior of the follicle to the exterior site, thus to an inside-outsignaling in the preovulatory period. The concept is that, in the first phase of the ovulatory process, the TLR-signaling in $\mathrm{CK}^{+}$cells is shaped by co-regulatory systems (complement receptor 1q, receptors for complement subunit 3a and 5a, Wnt-signaling) in support of tissue wounding/rupture (Fig. 1A). Cytokines and chemokines from the granulosa cell layer activate cells in the thecal cell layer in a paracrine manner. Here cells positive for CD117 tyrosin kinase receptor (KIT) develop (Spanel-Borowski et al., 2007). Segmented leukocytes are recruited and amplify the inflammatory pattern to mediate capillary sprouting and connective tissue degradation. The inside-out-signaling comes to an end with the expulsion of the oocyte by contraction of the follicle wall. The subsequent outside-in-signaling from the former thecal cell layer towards the granulosa cell layer orchestrates tissue repair (Fig. 1B). The microvascular bed stabilizes, granulosa and thecal cell luteinize, connective tissue replaces the former antrum. The KIT-KIT ligand system comes into play, a system responsible for cell migration and differentiation (Rönnstrand, 2004). According to immunostained sections KITpositive $\left(\mathrm{KIT}^{+}\right)$thecal cells are reinforced in the freshly ruptured follicle and, after basement membrane degradation, mingle with the adjacent granulosa cells (Spanel-Borowski et al., 2007). A cross-talk between $\mathrm{CK}^{+}$granulosa cells and $\mathrm{KIT}^{+}$thecal cells might loosen intercellular contacts and contribute to the postulated conversion of $\mathrm{CK}^{+}$cells into granulosalike luteal cells. The tachykinin-NK-1R system is favored as co-regulatory system as well (see 4). The complex world of molecule interactions between $\mathrm{CK}^{+}$cells and $\mathrm{KIT}^{+}$cells is totally unknown.

\section{Clinical Challenges and Summary}


The concept of INIM force in endocrine function of the ovary provides a novel strategy in the therapy of ovarian disorders. They might depend on inadequate activation or inhibition of danger TLR signaling through $\mathrm{CK}^{+}$granulosa cells. The overactivation of inflammatory signaling could cause the life-threatening general edema due to VEGF overproduction in women with the hyperstimulation syndrome (Kahnberg et al., 2009). Likewise overactivation of the inflammatory cascade could lead to atypical follicle ruptures with intra-ovarian oocyte release and striking tissue damage in superovulated ovaries (Spanel-Borowski, 2010). On the other hand, inhibition of TLR signaling explains anovulation disorders like the luteinized and unruptured follicle syndrome with high progesterone levels (Qublan et al., 2006) and the PCOS with androgen excess (Wild et al., 2010). Obese women suffer from anovulations. The cause could an excessive oxidative stress, which is indicated by higher levels of oxLDL in the follicular fluid of obese women with and without PCOS compared to normal-weight women (Bausenwein et al., 2010). Of interest, catalase activity as antioxidant-defence system is augmented in the follicular fluid of obese women and in the supernatant of oxLDL treated $\mathrm{CK}^{+}$granulosa cell cultures (Bausenwein et al., 2010; Serke et al., 2010). Thus, catalase activitity could become a parameter of oxidative stress in assisted reproductive treatment. Obese women of older reproductive age show up to $50 \%$ of dead granulosa cells in the fresh follicle harvest (Vilser et al., 2010). The findings indicate that danger signals/alarmins are unbalanced and INIM action out of order in the ovary. Because regular body excercises and food restriction can restore ovulation in obese women (Rachon and Teede, 2010; Thomson et al., 2010), life style changes might contribute to INIM balance in the ovary. Wedge resection and ovarian drilling, which both are effective in PCOS women (Api, 2009), could contribute to beneficial INIM function. The surgical interventions leave no harm, which reflects the enormous self-healing potential of the ovary. Of course, INIM does not stand alone in the immune control of ovarian function. It interacts with the adaptive immunity. The conversation between the two powerful systems probably changes in intensity in dependence of the local need. A low $\mathrm{T}$ cell number in the preovulatory follicle wall might signify a limited interaction with the adaptive immunity, whereas augmented $\mathrm{T}$ cells in the CL of regression speaks for exchanges between the two immune systems (Best et al., 1996; Spanel-Borowski et al., 1997; Bauer et al., 2001). A disturbed conversation between INIM and adaptive immunity is reflected by altered $\mathrm{T}$ cell profiles in the follicular fluid of patients with idiopathic infertility and in ovaries with premature ovarian failure due to autoimmune damage (Lukassen et al., 2003; Vujovic, 2009). It is noteworthy that ovarian cancer preferentially develops in women 
above the sixties when folliculogenesis and thus ovarian INIM function has ceased (Kumar et al., 2009). Because DCs process antigens and train naïve T cells to become helper and suppressor cells (Banchereau and Steinman, 1998; Mellman and Steinman, 2001; Turvey and Broide, 2010), DCs are key players between INIM and adaptive immunity. As documented thoroughly, the $\mathrm{CK}^{+}$cells are the promising candidate for immature DCs in preovulatory follicles, and granulosa-like cells for mature DC in the CL (Spanel-Borowski, 2010).

Innate immunity is being detected as mighty force for the regulation of tissue disintegration and integrity through sterile inflammation (Medzhitov, 2010b). The ovary is a site with controlled tissue damage and repair, which have been judged as footmarks of INIM (SpanelBorowski, 2010). The ovary is thus a model of choice to get insights into the physiological INIM function, a still hidden aspect. The ultimate trigger for ovulation induction appears to be the increase in oxidative stress/ROS within the preovulatory follicle. As long as INIM signaling is balanced by a restricted cell death of granulosa cells, the molecular sequence is beneficial for the ovulatory process. Future generations have to unravel the cross-talk of ovarian INIM with the adaptive immunity and the endocrine system. The efforts will generate alternate strategies for the treatment of ovarian disorders. Years of work lie adhead to disclose the complexity of the INIM world as beneficial danger signaling cascade not only in the ovulatory event but also in follicular atresia and luteolysis. The present concept opens an exciting new field of INIIM research and renovates the general interest in the biology of the ovary.

\section{References}

Adashi, E.Y., 1990. The potential relevance of cytokines to ovarian physiology: the emerging role of resident ovarian cells of the whilte blood cell series. Endocrine Reviews 11, 454-.

Angelucci, S., Ciavardelli, D., Di, G.F., Eleuterio, E., Sulpizio, M., Tiboni, G.M., Giampietro, F., Palumbo, P., Di, I.C., 2006. Proteome analysis of human follicular fluid. Biochim Biophys Acta 1764, 1775-1785.

Api, M., 2009. Is ovarian reserve diminished after laparoscopic ovarian drilling? Gynecol Endocrinol 25, 159-165.

Appasamy, M., Jauniaux, E., Serhal, P., Al-Qahtani, A., Groome, N.P., Muttukrishna, S., 2008. Evaluation of the relationship between follicular fluid oxidative stress, ovarian hormones, and response to gonadotropin stimulation. Fertil Steril 89, 912-921. 
Aust, G., Simchen, C., Heider, U., Hmeidan, F.A., Blumenauer, V., Spanel-Borowski, K., 2000. Eosinophils in the human corpus luteum: the role of RANTES and eotaxin in eosinophil attraction into periovulatory structures. Mol Hum Reprod 6, 1085-1091.

Banchereau, J., Steinman, R.M., 1998. Dendritic cells and the control of immunity. Nature $392,245-252$.

Bauer, M., Reibiger, I., Spanel-Borowski, K., 2001. Leucocyte proliferation in the bovine corpus luteum. Reproduction 121, 297-305.

Bausenwein, J., Serke, H., Eberle, K., Hirrlinger, J., Jogschies, P., Hmeidan, F.A., Blumenauer, V., Spanel-Borowski, K., 2010. Elevated levels of oxidized low-density lipoprotein and of catalase activity in follicular fluid of obese women. Mol Hum Reprod $16,117-124$.

Berisha, B., Schams, D., 2005. Ovarian function in ruminants. Domest Anim Endocrinol 29, $305-317$.

Best, C.L., Pudney, J., Welch, W.R., Burger, N., Hill, J.A., 1996. Localization and characterization of white blood cell populations within the. Hum Reprod 11, 790-797.

Bianchi, M.E., 2007. DAMPs, PAMPs and alarmins: all we need to know about danger. J Leukoc Biol 81, 1-5.

Billiau, A., Matthys, P., 2009. Interferon-gamma: a historical perspective. Cytokine Growth Factor Rev 20, 97-113.

Blanchard, C., Rothenberg, M.E., 2009. Biology of the eosinophil. Adv Immunol 101, 81121.

Boyer, A., Lapointe, E., Zheng, X., Cowan, R.G., Li, H., Quirk, S.M., DeMayo, F.J., Richards, J.S., Boerboom, D., 2010. WNT4 is required for normal ovarian follicle development and female fertility. FASEB J 24, 3010-3025.

Brännström, M., Enskog, A., 2002. Leukocyte networks and ovulation. J Reprod Immunol 57, $47-60$.

Brännström, M., Norman, R.J., Seamark, R.F., Robertson, S.A., 1994a. Rat ovary produces cytokines during ovulation. Biol Reprod 50, 88-94.

Brännström, M., Pascoe, V., Norman, R.J., McClure, N., 1994b. Localization of leukocyte subsets in the follicle wall and in the corpus luteum. Fertil Steril 61, 488-495.

Brylla, E., Aust, G., Geyer, M., Uckermann, O., Loffler, S., Spanel-Borowski, K., 2005. Coexpression of preprotachykinin A and B transcripts in the bovine corpus luteum and evidence for functional neurokinin receptor activity in luteal endothelial cells and ovarian macrophages. Regul Pept 125, 125-133. 
Chen, C.J., Kono, H., Golenbock, D., Reed, G., Akira, S., Rock, K.L., 2007. Identification of a key pathway required for the sterile inflammatory response triggered by dying cells. Nat Med 13, 851-856.

Dandapat, A., Hu, C., Sun, L., Mehta, J.L., 2007. Small concentrations of oxLDL induce capillary tube formation from endothelial cells via LOX-1-dependent redox-sensitive pathway. Arterioscler Thromb Vasc Biol 27, 2435-2442.

Das, S., Chattopadhyay, R., Ghosh, S., Ghosh, S., Goswami, S.K., Chakravarty, B.N., Chaudhury, K., 2006. Reactive oxygen species level in follicular fluid--embryo quality marker in IVF? Hum Reprod 21, 2403-2407.

Debeljuk, L., 2006. Tachykinins and ovarian function in mammals. Peptides 27, 736-742.

Devoto, L., Fuentes, A., Kohen, P., Cespedes, P., Palomino, A., Pommer, R., Munoz, A., Strauss, J.3., 2009. The human corpus luteum: life cycle and function in natural cycles. Fertil Steril 92, 1067-1079.

Duerrschmidt, N., Zabirnyk, O., Nowicki, M., Ricken, A., Hmeidan, F.A., Blumenauer, V., Borlak, J., Spanel-Borowski, K., 2006. Lectin-like oxidized low-density lipoprotein receptor-1-mediated autophagy in human granulosa cells as an alternative of programmed cell death. Endocrinology 147, 3851-3860.

Endo,Y., Takahashi, M., Fujita, T., 2006. Lectin complement system and pattern recognition. Immunobiology 211, 283-293.

Espey, L.L., 1994. Current status of the hypothesis that mammalian ovulation is comparable to an. Biol Reprod 50, 233-238.

Espey, L.L., 2006. Comprehensive analysis of ovarian gene expression during ovulation using. Methods Mol Biol 317, 219-241.

Fraser, H.M., Duncan, W.C., 2005. Vascular morphogenesis in the primate ovary. Angiogenesis 8, 101-116.

Giampietro, F., Sancilio, S., Tiboni, G.M., Rana, R.A., Di, P.R., 2006. Levels of apoptosis in human granulosa cells seem to be comparable after therapy with a gonadotropin-releasing hormone agonist or antagonist. Fertil Steril 85, 412-419.

Gordon, M.D., Dionne, M.S., Schneider, D.S., Nusse, R., 2005. WntD is a feedback inhibitor of Dorsal/NF-kappaB in Drosophila development and. Nature 437, 746-749.

Grøndahl, M.L., Borup, R., Lee, Y.B., Myrhoj, V., Meinertz, H., Sorensen, S., 2009.

Differences in gene expression of granulosa cells from women undergoing controlled ovarian hyperstimulation with either recombinant follicle-stimulating hormone or highly purified human menopausal gonadotropin. Fertil Steril 91, 1820-1830. 
Hajishengallis, G., Lambris, J.D., 2010. Crosstalk pathways between Toll-like receptors and the complement system. Trends Immunol 31, 154-163.

Hanukoglu, I., 2006. Antioxidant protective mechanisms against reactive oxygen species (ROS) generated. Drug Metab Rev 38, 171-196.

Hernandez-Gonzalez, I., Gonzalez-Robayna, I., Shimada, M., Wayne, C.M., Ochsner, S.A., White, L., Richards, J.S., 2006. Gene expression profiles of cumulus cell oocyte complexes during ovulation reveal cumulus cells express neuronal and immune-related genes: does this expand their role in the ovulation process? Mol Endocrinol 20, 1300-1321.

Iwasaki, A., Medzhitov, R., 2010. Regulation of adaptive immunity by the innate immune system. Science 327, 291-295.

Kahnberg, A., Enskog, A., Brännström, M., Lundin, K., Bergh, C., 2009. Prediction of ovarian hyperstimulation syndrome in women undergoing in vitro fertilization. Acta Obstet Gynecol Scand 88, 1373-1381.

Köhl, J., 2006. Self, non-self, and danger: a complementary view. Advances in experimental medicine and biology 586, 71-94.

Kumar, H., Kawai, T., Akira, S., 2009. Toll-like receptors and innate immunity. Biochem Biophys Res Commun 388, 621-625.

Lambrecht, B.N., 2001. Immunologists getting nervous: neuropeptides, dendritic cells and T cell. Respir Res 2, 133-138.

Löffler, S., Horn, L.C., Weber, W., Spanel-Borowski, K., 2000. The transient disappearance of cytokeratin in human fetal and adult ovaries. Anat Embryol (Berl) 201, 207-215.

Löffler, S., Schulz, A., Brylla, E., Nieber, K., Spanel-Borowski, K., 2004a. Transcripts of neurokinin B and neurokinin 3 receptor in superovulated rat ovaries and increased number of corpora lutea as a non-specific effect of intraperitoneal agonist application. Regul Pept $122,131-137$.

Löffler, S., Schulz, A., Hunt, S.P., Spanel-Borowski, K., 2004b. Increased formation of corpora lutea in neurokinin 1-receptor deficient mice. Mol Reprod Dev 68, 408-414.

Lukassen, H.G., van, d.M.A., van, L.M.J., Lindeman, E.J., Joosten, I., Braat, D.D., 2003. The proportion of follicular fluid CD16+CD56DIM NK cells is increased in IVF patients with idiopathic infertility. J Reprod Immunol 60, 71-84.

Matzinger, P., 2002. The danger model: a renewed sense of self. Science 296, 301-305.

Matzinger, P., 2007. Friendly and dangerous signals: is the tissue in control? Nat Immunol 8, $11-13$.

Medzhitov, R., 2008. Origin and physiological roles of inflammation. Nature 454, 428-435. 
Medzhitov, R., 2010a. Inflammation 2010: new adventures of an old flame. Cell 140, 771776.

Medzhitov, R., 2010b. Innate immunity: quo vadis? Nat Immunol 11, 551-553.

Mehta, J.L., Chen, J., Hermonat, P.L., Romeo, F., Novelli, G., 2006. Lectin-like, oxidized low-density lipoprotein receptor-1 (LOX-1): a critical player in the development of atherosclerosis and related disorders. Cardiovasc Res 69, 36-45.

Mellman, I., Steinman, R.M., 2001. Dendritic cells: specialized and regulated antigen processing machines. Cell 106, 255-258.

Miller, Y.I., Viriyakosol, S., Binder, C.J., Feramisco, J.R., Kirkland, T.N., Witztum, J.L., 2003. Minimally modified LDL binds to CD14, induces macrophage spreading via TLR4/MD-2, and inhibits phagocytosis of apoptotic cells. J Biol Chem 278, 1561-1568.

Munitz, A., Levi-Schaffer, F., 2004. Eosinophils: 'new' roles for 'old' cells. Allergy 59, 268 275.

Murdoch, W.J., Steadman, L.E., 1991. Investigations concerning the relationship of ovarian eosinophilia to ovulation. Am J Reprod Immunol 25, 81-87.

O'Connor, T.M., O'Connell, J., O'Brien, D.I., Goode, T., Bredin, C.P., Shanahan, F., 2004. The role of substance P in inflammatory disease. J Cell Physiol 201, 167-180.

Oktem, O., Oktay, K., 2008. The ovary: anatomy and function throughout human life. Ann N Y Acad Sci 1127, 1-9.

O'Neill, L.A., Bowie, A.G., 2007. The family of five: TIR-domain-containing adaptors in Toll-like receptor. Nat Rev Immunol 7, 353-364.

Oyawoye, O., Abdel, G.A., Garner, A., Constantinovici, N., Perrett, C., Hardiman, P., 2003. Antioxidants and reactive oxygen species in follicular fluid of women undergoing IVF: relationship to outcome. Hum Reprod 18, 2270-2274.

Pasqualotto, E.B., Agarwal, A., Sharma, R.K., Izzo, V.M., Pinotti, J.A., Joshi, N.J., Rose, B.I., 2004. Effect of oxidative stress in follicular fluid on the outcome of assisted reproductive procedures. Fertil Steril 81, 973-976.

Pereira, C.P., Bachli, E.B., Schoedon, G., 2009. The wnt pathway: a macrophage effector molecule that triggers inflammation. Curr Atheroscler Rep 11, 236-242.

Qublan, H., Amarin, Z., Nawasreh, M., Diab, F., Malkawi, S., Al-Ahmad, N., Balawneh, M., 2006. Luteinized unruptured follicle syndrome: incidence and recurrence rate in infertile women with unexplained infertility undergoing intrauterine insemination. Hum Reprod 21, 2110-2113. 
Rachon, D., Teede, H., 2010. Ovarian function and obesity--interrelationship, impact on women's reproductive lifespan and treatment options. Mol Cell Endocrinol 316, 172-179.

Reibiger, I., Aust, G., Tscheudschilsuren, G., Beyer, R., Gebhardt, C., Spanel-Borowski, K., 2001. The expression of substance $P$ and its neurokinin-1 receptor mRNA in the bovine corpus luteum of early developmental stage. Neurosci Lett 299, 49-52.

Reibiger, I., Spanel-Borowski, K., 2000. Difference in localization of eosinophils and mast cells in the bovine ovary. J Reprod Fertil 118, 243-249.

Richards, J.S., Liu, Z., Shimada, M., 2008. Immune-like mechanisms in ovulation. Trends Endocrinol Metab 19, 191-196.

Richards, J.S., Russell, D.L., Ochsner, S., Espey, L.L., 2002. Ovulation: new dimensions and new regulators of the inflammatory-like response. Annu Rev Physiol 64, 69-92.

Rock, K.L., Latz, E., Ontiveros, F., Kono, H., 2010. The sterile inflammatory response. Annu Rev Immunol 28, 321-342.

Rohm, F., Spanel-Borowski, K., Eichler, W., Aust, G., 2002. Correlation between expression of selectins and migration of eosinophils into the bovine ovary during the periovulatory period. Cell Tissue Res 309, 313-322.

Rönnstrand, L., 2004. Signal transduction via the stem cell factor receptor/c-Kit. Cell Mol Life Sci 61, 2535-2548.

Serke, H., Bausenwein, J., Hirrlinger, J., Nowicki, M., Vilser, C., Jogschies, P., Hmeidan, F.A., Blumenauer, V., Spanel-Borowski, K., 2010. Granulosa Cell Subtypes Vary in Response to Oxidized Low-Density Lipoprotein as Regards Specific Lipoprotein Receptors and Antioxidant Enzyme Activity. J Clin Endocrinol Metab.

Serke, H., Vilser, C., Nowicki, M., Hmeidan, F.A., Blumenauer, V., Hummitzsch, K., Losche, A., Spanel-Borowski, K., 2009. Granulosa cell subtypes respond by autophagy or cell death to oxLDL-dependent activation of the oxidized lipoprotein receptor 1 and toll-like 4 receptor. Autophagy 5, 991-1003.

Severini, C., Improta, G., Falconieri-Erspamer, G., Salvadori, S., Erspamer, V., 2002. The tachykinin peptide family. Pharmacol Rev 54, 285-322.

Shimada, M., Hernandez-Gonzalez, I., Gonzalez-Robanya, I., Richards, J.S., 2006. Induced expression of pattern recognition receptors in cumulus oocyte complexes: novel evidence for innate immune-like functions during ovulation. Mol Endocrinol 20, 3228-3239.

Shimada, M., Yanai, Y., Okazaki, T., Noma, N., Kawashima, I., Mori, T., Richards, J.S., 2008. Hyaluronan fragments generated by sperm-secreted hyaluronidase stimulate.

Development 135, 2001-2011. 
Sonderegger, S., Pollheimer, J., Knofler, M., 2010. Wnt signalling in implantation, decidualisation and placental differentiation--review. Placenta 31, 839-847.

Spanel-Borowski, K., Rahner, P., Ricken, A.M., 1997. Immunolocalization of CD18-positive cells in the bovine ovary. J Reprod Fertil 111, 197-205.

Spanel-Borowski, K., Sass, K., Loffler, S., Brylla, E., Sakurai, M., Ricken, A.M., 2007. KIT receptor-positive cells in the bovine corpus luteum are primarily theca-derived small luteal cells. Reproduction 134, 625-634.

Spanel-Borowski, K., 2010. Footmarks of innate immunity and cytokeratin-positive cells as potential dendritic cells.

Stewart, C.R., Stuart, L.M., Wilkinson, K., van, G.J.M., Deng, J., Halle, A., Rayner, K.J., Boyer, L., Zhong, R., Frazier, W.A., Lacy-Hulbert, A., Khoury, J.E., Golenbock, D.T., Moore, K.J., 2010. CD36 ligands promote sterile inflammation through assembly of a Tolllike. Nat Immunol 11, 155-161.

Stocco, C., Telleria, C., Gibori, G., 2007. The molecular control of corpus luteum formation, function, and regression. Endocr Rev 28, 117-149.

Takeda, K., Akira, S., 2005. Toll-like receptors in innate immunity. Int Immunol 17, 1-14.

Takeuchi, O., Akira, S., 2010. Pattern recognition receptors and inflammation. Cell 140, 805820.

Tatone, C., Amicarelli, F., Carbone, M.C., Monteleone, P., Caserta, D., Marci, R., Artini, P.G., Piomboni, P., Focarelli, R., 2008. Cellular and molecular aspects of ovarian follicle ageing. Hum Reprod Update 14, 131-142.

Thomson, R.L., Buckley, J.D., Brinkworth, G.D., 2010. Exercise for the treatment and management of overweight women with polycystic ovary syndrome: a review of the literature. Obes Rev.

Tsai, N.M., Hsieh, R.H., Au, H.K., Shieh, M.J., Huang, S.Y., Tzeng, C.R., 2005. Effects of gonadotrophin-releasing hormone agonists on apoptosis of granulosa cells. Ann N Y Acad Sci 1042, 531-537.

Turvey, S.E., Broide, D.H., 2010. Innate immunity. J Allergy Clin Immunol 125, S24-32.

van Wezel, I.L., Dharmarajan, A.M., Lavranos, T.C., Rodgers, R.J., 1999. Evidence for alternative pathways of granulosa cell death in healthy and slightly. Endocrinology 140, 2602-2612.

Vilser, C., Hueller, H., Nowicki, M., Hmeidan, F.A., Blumenauer, V., Spanel-Borowski, K., 2010. The variable expression of lectin-like oxidized low-density lipoprotein receptor 
(LOX-1) and signs of autophagy and apoptosis in freshly harvested human granulosa cells depend on gonadotropin dose, age, and body weight. Fertil Steril 93, 2706-2715.

Vujovic, S., 2009. Aetiology of premature ovarian failure. Menopause Int 15, 72-75.

Wild, R.A., Carmina, E., Diamanti-Kandarakis, E., Dokras, A., Escobar-Morreale, H.F., Futterweit, W., Lobo, R., Norman, R.J., Talbott, E., Dumesic, D.A., 2010. Assessment of cardiovascular risk and prevention of cardiovascular disease in women with the polycystic ovary syndrome: a consensus statement by the Androgen Excess and Polycystic Ovary Syndrome (AE-PCOS) Society. J Clin Endocrinol Metab 95, 2038-2049.

Wright, J.W., Pejovic, T., Lawson, M., Jurevic, L., Hobbs, T., Stouffer, R.L., 2010. Ovulation in the absence of the ovarian surface epithelium in the primate. Biol Reprod 82, 599-605. 


\section{Legends}

\section{Fig. 1}

Working hypothesis for the inside-out signaling of $\mathrm{CK}^{+}$cells as effector cells of INIM orchestrating follicular rupture in (A). The inside-out cascade commands the inflammatory response with breakdown of the extracellular matrix (ECM) under the control of the Myd88dependent TLR signaling. In (B) the outside-in signaling mediates the healing phase being responsible for the transformation into a CL. For outside-in-signalin, the TLR4 cascade preferentially relates to the TIR-domain-containing adaptor protein producing IFN- $\beta$ (TRIF) leading to the interferon-regulatory factor 3 (IFR-3) transcription factors for tissue repair. Anti-inflammatory processes dominate. Pathways for disintegration and regeneration overlap, yet the dominance shifts with time. Pathways are simplified. Theoretical associations are in grey. Modified from Spanel-Borowski (2010)

A: The $\mathrm{CK}^{+}$cells create a microenvironment by prominent cell junctions. The basement membrane is intact, fibroblasts and $\mathrm{KIT}^{+}$cells are withhold in the thecal cell layer. The Gcoupled receptors (complement receptor 3R for C3a and C5) as well as for Wnt signaling) might act independently or co-regulate the TLR4 pathway in $\mathrm{CK}^{+}$cells by modulating at the receptor level or downstream. The C3R-dependent pathways of mitogen-activated protein kinases (MAPKs) are grouped into the extracellular signal-related kinases (ERK), c-Jun-Nterminal kinases (JNK) and the p38 mitogen activated protein kinases (p38). The C3Rdependent pathway also comprises the Janus kinase-signal transducer and activator of transcription (JAK-STAT), an alternate second messenger system. The Wnt-signaling generates $\beta$-catenin for adherence junctions in $\mathrm{CK}^{+}$granulosa cells. The final TLR4 signaling is connected with the Myd 88-adaptor protein, which activates either the inihibiting kinases (IKK complex) as core element of nuclear factor- $\mathrm{\kappa b}(\mathrm{NF}-\kappa \mathrm{B})$ cascade or MAPKs for activator protein-1 (AP-1). Altogether, signaling supports pro-inflammation, controls cell proliferation, differentiation and cell death. It generates immunoregulatory responses for the recruitment of monocytes and neutrophils through endothelial cell activation.

B. The $\mathrm{CK}^{+}$cells beome mobile after loss of cell junctions. The basement membrane disintegrates, fibroblasts and $\mathrm{KIT}^{+}$cells proliferate and migrate towards the former antrum. The TLR4 signaling through the TRIF-IRF3-dependent gateway finally activates IFN type I genes. The tachykinin-tachykinin-receptor cascade might play a co-regulatory role. The final outcome of the anti-inflammatory events relates to immigration of eosinophils. Their specific 
factors could mediate sprouting and maturation of capillaries as well connective tissue growth. 


\section{A: Rupture process as inside-out signaling within $>12 \mathrm{~h}$}

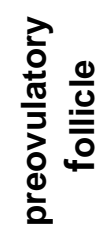

signal direction

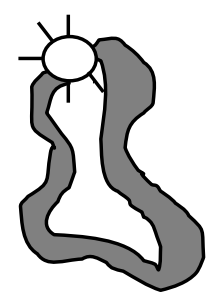

- monocytes, neutrophils

- fibrinolytic activity

- breakdown of ECM

- vascular permeabolity

- capillary sprouting, onset

- quiescent Kit+ thecal cells

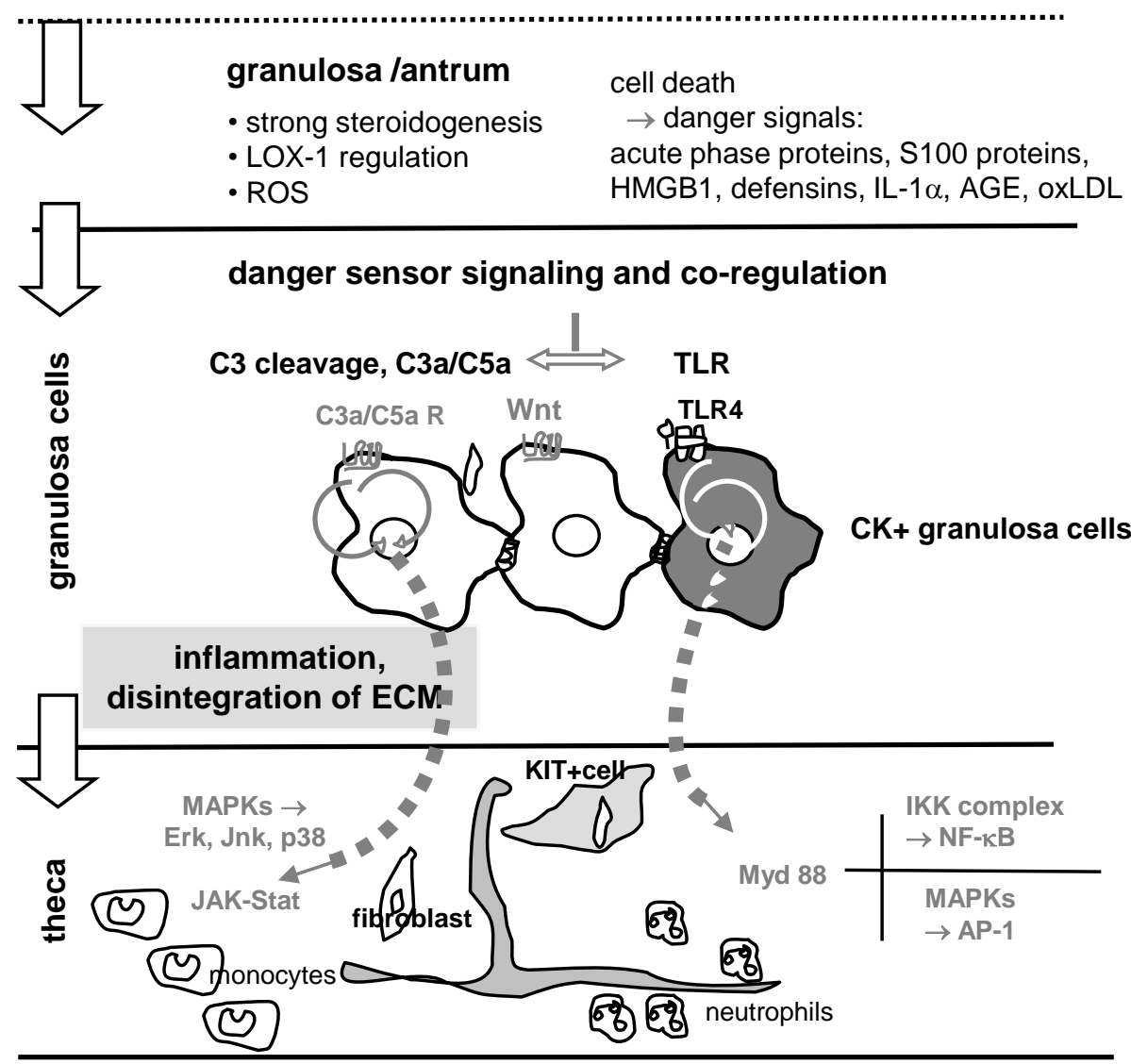

Fig. $1 \mathrm{~A}$

Spanel-Borowski 
B: Repair phase as outside-in signaling within $>24 \mathrm{~h}$
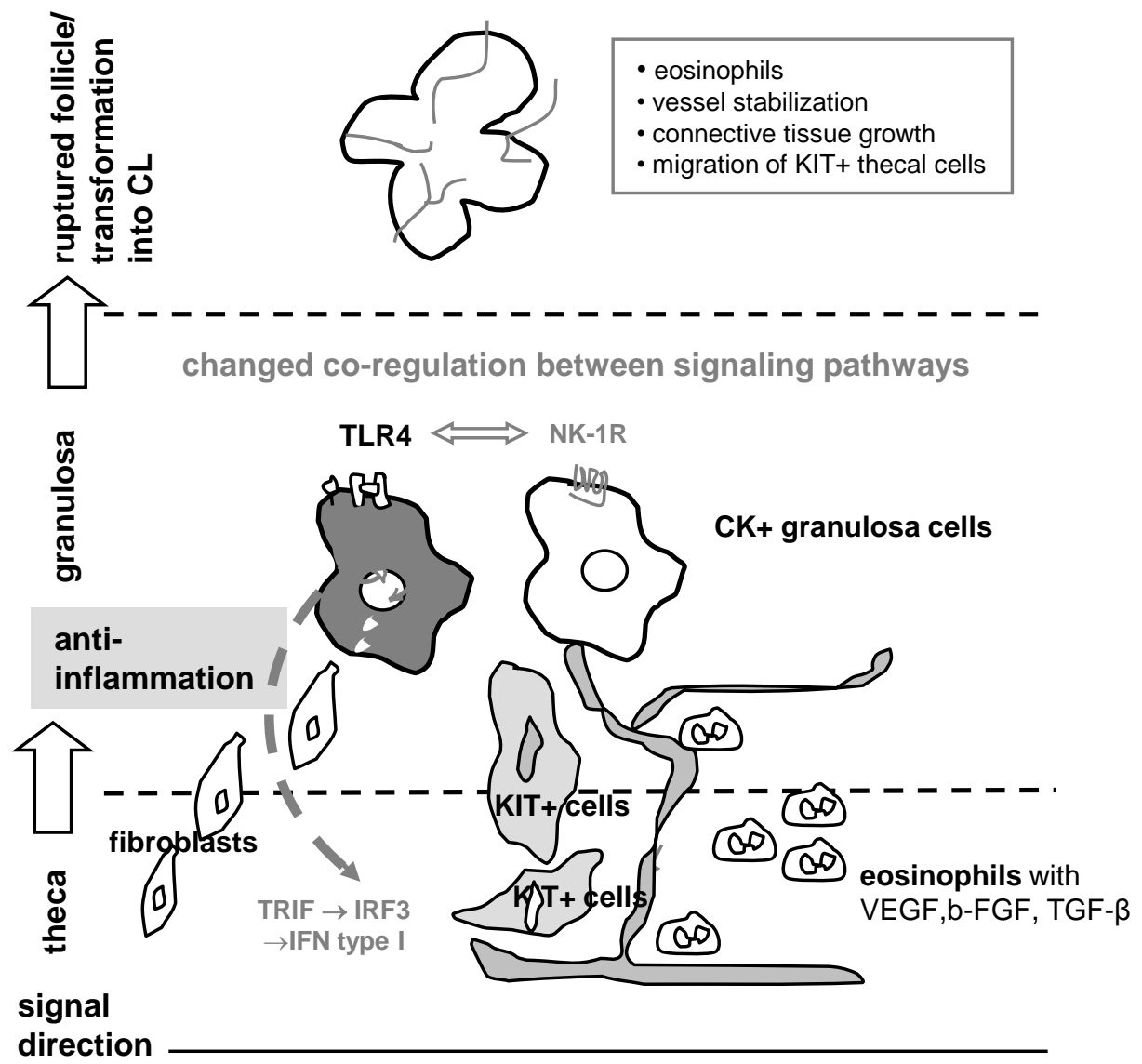

Fig. 1B

Spanel-Borowski 